\title{
Compulsory English Language Teaching in Taibah University at Undergraduate Level: Problems and Challenges
}

\author{
Waquar Ahmad Khan \\ Assistant Professor \\ Department of Languages and Translation, College of Science and Arts \\ Taibah University, Al Ula Campus, Madinah \\ Kingdom of Saudi Arabia (KSA)
}

Received: September 28, 2020 Accepted: October 16, 2020 Published: October 18, 2020

doi:10.5296/jsel.v9i1.17848 URL: https://doi.org/10.5296/jsel.v9i1.17848

\begin{abstract}
Believe it or not, attitude can be an obstacle. To learn any language, positive attitude is prerequisite, and a learner needs to go for it. Learning English as a foreign language is certainly not an easy task. Particularly if you are learning English in a non-English-speaking country. English language teaching and learning always attracts the attention of young minds and young generations across the globe for many pedagogical, sociolinguistic, and economic reasons. The present study focuses on teaching English to the students of Arabic and Islamic studies as their compulsory paper at Taibah University. The research paper is based on action research carried out at Al Ula campus, Taibah University. Compulsory English course specification caters to a mixed and mostly large group of students who belong to different social, cultural, economic, and regional background. It is because of this reason; the primary focus of this study is to find out the problems and challenges among learners and teachers. More precisely, the impact and interference of mother tongue (Arabic), lack of opportunity to use English in day to day activities, approach concerning learning English, and inefficacy of EFL learning and teaching.
\end{abstract}

Keywords: L1 and L2, English language teaching, globalization, curriculum, mother tongue 


\section{Introduction}

Teaching English as a foreign language in the Kingdom of Saudi Arabia is still a challenging task. Due to a quick expansion of English language teaching market in Saudi Arabia, huge professional development opportunities are emerging. Keeping in mind professional development opportunities, numerous steps have been taken by the ministry of higher education to promote the procedure of teaching and learning English, still the system needs to work hard to achieve the target of teaching and learning English. Lots of efforts are needed for improvement. Al- Nasser (2015), has stated that "the influence of mother tongue works as a major obstacle to learn English". Today, English is not confined for science and technology, it is also a language of business and trade. Rahman (2013), has identified that, "the prescribed textbooks with minimal level of linguistics features fail to meet the requirements of the learners. In the school the students take English as a subject which is required to pass only" P.113. The second point with regard to compulsory English course is how much has to be taught? How much a student is supposed to know at the end of the course? Which communication skills need special attention according to the needs of the learners and the demands? Does language instruction help the students at all? What kind of language pedagogy is required? What kind of technique a teacher should employ? A value-based analysis is to be done keeping in mind what and how the students need to know about English language. As, I have mentioned earlier, ministry of higher education is providing necessary tools for the students to learn English language in addition to their mother tongue (Arabic). But the attitude towards teaching and learning needs drastic change, urgent modification is required at the grass root level.

According to Khan (2011), The teaching of English at universities of Saudi Arabia mainly cater two interesting aspects.

(1) It extends the substance of English for the students, and

(2) It builds up the foundation and focus on primary and secondary aspects of English language learning, which will be extended in the emergence of future requirements.

Al-Qadi (1992), believes "that students will be able to communicate and represent their culture to the world using this language". Moreover, previous studies indicate, a consistent effort taken by ministry of higher education. There has been high tended interest in the kingdom for learning English as a foreign language. Various job opportunities have been created in the kingdom by the Saudi government where English language is mandatory which attracts youths to go for learning English. Inspite of all efforts of various agencies the desired result is still miles away. One needs to keep in mind the challenging and often complicated process of learning and teaching English in Saudi Arabia. Since compulsory English course has to cater a very heterogeneous and mostly large groups of students belonging to divergent social, regional, and linguistic background. It poses challenges from the stage of determining 
the needs and objectives.

The compulsory educational system consists of four levels:

(A) The primary level, which consists of six grades.

(B) The intermediate level,

(C) The secondary level, and

(D) Higher Secondary level (Graduation and above)

Each level contains three grades. Learning English alphabets starts in the last semester in the primary school which consist four classes weekly of 45 minutes each and students are not even exposed to capital and small letters of English language. On the other hand, it has been observed that students from intermediate and secondary levels are not up to the mark in the basics of English language at Al Ula. Literature reviews indicates many reasons leading to the above circumstances. Some of the important points are as under.

(A) Lack of awareness about the importance of English,

(B) The low standard of teaching at primary and secondary level,

(C) Present curriculum and the teaching strategies used inside the classroom, and

(D) Social and cultural background.

As compulsory English course covers basics of listening, speaking, reading, writing, and grammar which disguises large number of students who belongs to different linguistic backgrounds. It creates challenges to determine the objectives, and needs of syllabus design, material preparation, and teaching and testing evaluation.

\section{Objectives of the Study}

The study had the following objectives: -

1. To find out the EFL teaching /learning problems at Al Ula campus,

2. To find out the causes of these problems, and

3. To find out possible solutions of the existing problems.

\section{Literature Review}

Literature related to the English language teaching can be obtained in bulk, but studies in the present research are quite extraordinary. There is no doubt about the popularity of English language, possibly the most spoken language around the world. Many people select to learn English language simply to get good job, better placement, and connect more efficiently with people around the world. English is one of the simple languages to learn, but it does not 
mean this is a simple language to make mastery on it. Many a step are designed to learn a foreign language, and if a learner is aware of those designs, he has a greater chance of grasping the language in a short span of time. A significant text related to the difficulties has been revealed in the literature review which is mainly experienced by the Saudi students in general and specifically Taibah University students while learning English.

\subsection{Structural Differences between Arabic and English Language}

The most crucial problem faced by the students of Saudi Arabia in general lies in the common structural dissimilarities between the Arabic and the English language. English belongs to West Germanic language family whereas, Arabic belong Semitic language family. Similarly, their grammars are also different. We see, there are major dissimilarities in the syntax of those two languages. For example, Arabic writing does not use capitalization and uses another structure in punctuation. Mainly, two major types of sentence structures can be identified between English and Arabic language. (A) Nominal sentence, and (B) Verbal Sentence. Arabic has both nominal and verbal sentences whereas English has verbal sentences only. A formal sentence requires no verb of any kind. Spelling is also a big challenge among students of Saudi Arabia. Arabic language consists of only one letter per sound, so the spelling section is much more complex in English language. Pronunciation of English words is also puzzling to the students. Since Arab speakers often use Arabic phonetics to pronounce words. Rabab'ah (2005), clearly states in his paper, "The use of commas and conjunctions is also another difficulty for Arabic students because the usage is different in Arabic and English contexts."

\subsection{Lack of Motivation in Learning English}

Motivation plays an important role in building the habit towards individual learning. "The results of motivation are normally far reaching because it increases an individual's level of energy, determination towards reaching a specific goal, and directly affects the types of learning techniques used among learners thinking processes". Fan (2009).According to human development professionals, there are two kinds of motivation. (A) Extrinsic motivation, and (B) Intrinsic motivation.

(A) Extrinsic (External) Motivation: - is controlled by the learners outside surroundings and specific tasks.

(B) Intrinsic (Internal) Motivation: - Internal motivation gets the place inside or within the learners, meanwhile the objective of this can be considered as one of the precious motivation levels. Therefore, when relating the influence, intrinsic motivation considered as one of the effective learning processes. There are various factors which leads to the increase and decrease of internal motivation levels. Because of this tendency, instructors can have a considerable impact on their learners learning. The researcher wishes to share his observation regarding lack of intrinsic motivation in the context of teaching English as a foreign language at Taibahuniversity. It is not only frustrating the learners, but it is also frustrating the teachers who are the cornerstones of the educational process. Both kinds of motivation are important in a given context of education. 


\subsection{Role of Cultural Issues/Barrier}

Culture and language are two sides of a coin. Both are having different qualities which go well together. Language is used mutually as a carrier of culture as well as means of communication. Alptekin (1993), says, "Culture is socially acquired knowledge that plays an important role in the English language learning process". McGee \& Banks (1989), defined culture from a wider social and psychological perspective: "It is the values, symbols, interpretations, and perspectives that distinguish one people from another in modernized societies; it is not material objects and other tangible aspects of human societies. People within a culture usually interpret the meaning of symbols, artifacts, and behaviors in the same or in similar ways. "While teaching English language, this is very important for a teacher to know the culture of the target language and the culture of the learners. However, teachers in different parts of the world where foreign language is being taught still ignore the importance of culture as a part of language study. "The classroom is a place where the teacher is an established head and the student's role is defined in terms of 'quietness of loving to listen." Jamjoom (2009), as cited Elyas and Picard, (2010). In this connection, the relationship between teacher and students in the Al Ula campus is traditional and old; teachers pose an upper level in the classroom, this is called 'student-centered' pedagogy, which is not a common practice in today's teaching and learning process. Because of this inference majority of Saudi students are not familiar to interactive teaching programme, which directly provide proficiency in the English language. Wei (2005), stated, "Language without culture is unthinkable, so is human culture without language."

\subsection{Social and Environmental Issues}

"Positive educational environments are necessary to facilitate optimally adaptive student outcomes, including learning, motivation, school adjustment, and achievement".Eccles, Wigfield, \&Schiefele (1998).Goodenow (1992); Juvonen\& Weiner (1993), have observed that "schools and colleges does not only provide academic stuff, schools and classrooms are fundamentally a social place, and students go about their work in the presence of many peers and learn accordingly about academic and social life". The way mixing made by the students of Arabic background in their educational institutions is helpful in developing level of motivation in learning target language.

\section{Research Methodology}

This study was purely based on qualitative research method. The design was used to achieve an insight of the fundamental impulse, thoughts, and views. There are some common tools that have been included like group discussions, individual interviews, and participants observations. In this study the main data gathering tool was a questionnaire. The questionnaire consists of 07 questions, prepared in both English and Arabic language. 


\section{Macrothink}

\section{Participants}

The questionnaire for the study was developed after reviewing literature applicable for this topic. The questionnaire was consisting of basic seven questions. All the participants were from Taibah University, Al Ula campus, Male, Saudi national, age group between 18 to 26 years. As all the participants were researcher's students. Researcher was aware about understanding of their English language, keeping in mind the design of the questions was made in such a way respondent can easily understand (English to Arabic translation). The number of participants was one hundred twelve. Ninety-six participants submitted their questionnaire.

\subsection{Data Analysis}

The data was examined via statistical package for the social sciences (SPSS) statistics and the results and conclusion are displayed in the descriptive tables on percentile basis, showing the mean value and standard deviation for each of the items in the questionnaire.

Table 1. Questionnaire data $(\mathrm{N}=96)$

\begin{tabular}{|c|c|c|c|c|}
\hline S. No & Questions & Agree & Disagree & Undecided \\
\hline 1 & $\begin{array}{l}\text { Do you think a different grammar } \\
\text { makes English confusing? }\end{array}$ & 72 & 16 & 08 \\
\hline 2 & $\begin{array}{l}\text { Do you think a different alphabet makes } \\
\text { reading and writing difficult? }\end{array}$ & 68 & 23 & 05 \\
\hline 3 & $\begin{array}{l}\text { Do you think some English sounds are } \\
\text { difficult to pronounce? }\end{array}$ & 76 & 11 & 09 \\
\hline 4 & $\begin{array}{l}\text { Is there any fear of mistake in the mind while } \\
\text { you speak English? }\end{array}$ & 61 & 28 & 07 \\
\hline 5 & $\begin{array}{l}\text { Do you think learning English language is } \\
\text { today's demand? }\end{array}$ & 16 & 51 & 29 \\
\hline 6 & $\begin{array}{c}\text { Do you think cultural differences affecting } \\
\text { your English learning? }\end{array}$ & 64 & 18 & 14 \\
\hline 7 & $\begin{array}{l}\text { Do you think social networking sight like Face } \\
\text { Book, Twitter, and Instagram helps in learning } \\
\text { English language? }\end{array}$ & 40 & 47 & 09 \\
\hline
\end{tabular}


Table 1: Questionnaire data (N-96)

80

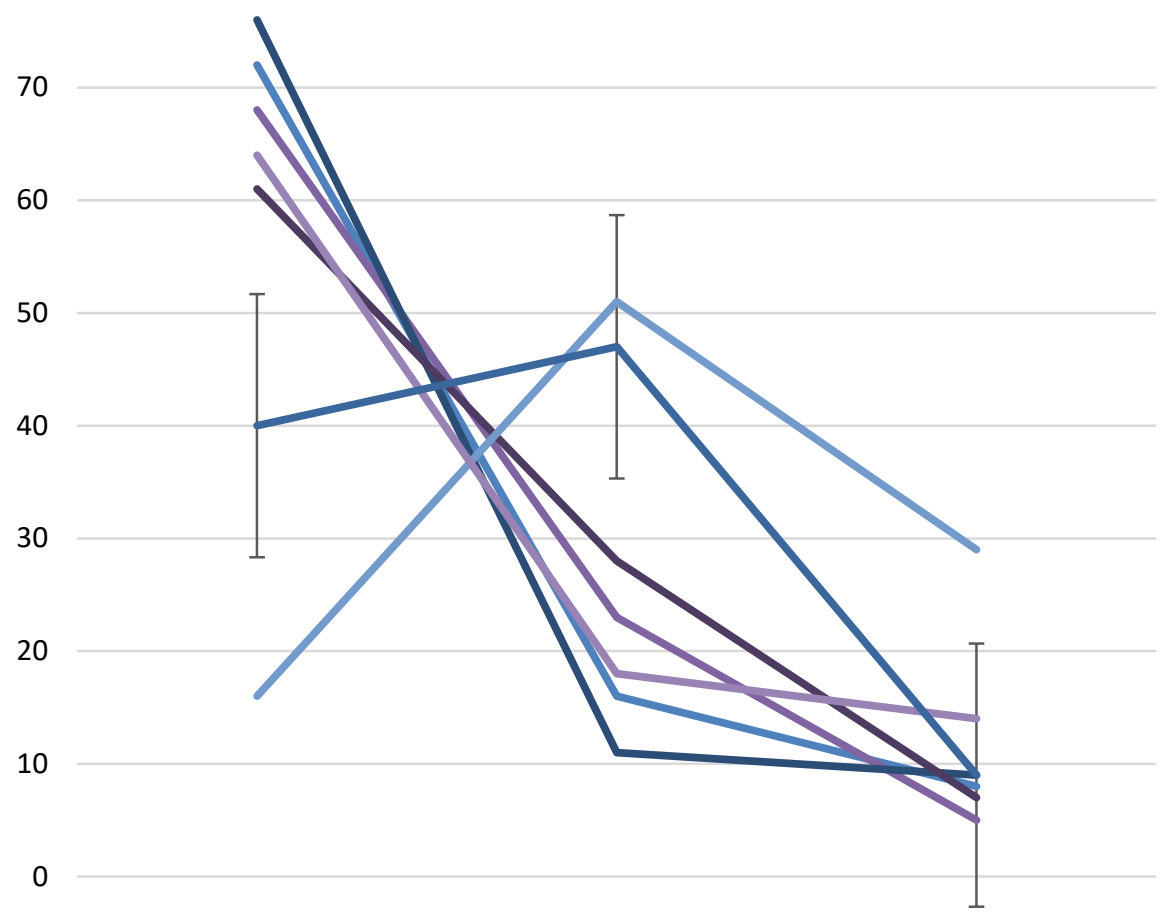

\begin{tabular}{r|c|c|c}
\multicolumn{1}{c|}{-10 } & Agree & Disagree & Undecided \\
\hline 1 & 72 & 16 & 8 \\
\hline 2 & 68 & 23 & 5 \\
\hline 3 & 76 & 11 & 9 \\
\hline 4 & 61 & 28 & 7 \\
\hline 5 & 16 & 51 & 29 \\
\hline 7 & 64 & 18 & 14 \\
\hline
\end{tabular}




\section{Results and Discussion}

(1) 72 respondents over $96(75.00 \%)$ agree that different grammar makes English confusing. Mainly in two grammatical points students of Al Ula in particular and Saudi Arabian students in general often face are the verb 'to be' and the present perfect aspect. The verb 'to be' is not used as frequently in Arabic as in English. The present perfect aspect makes confusion among Arabic speakers. It is widely spread and used even well-informed speakers of English using the present perfect to talk about things that occurred at a specific time in the past. For example, "I have seen him yesterday".

(2) 68 respondents over $96(70.83 \%)$ agree that different alphabet makes reading and writing difficult. As English is written from left to right, Arabic just opposite to it which looks very awkward to the Arabic speakers, they don't easily adjust in their reading and writing. Moreover, English has upper and lower-case letters whereas Arabic does not have. As part of the writing system, less attention has been given towards punctuation in the primary and secondary schools in the kingdom. Because of this it is common to find Arabic learners mixing capital and small letters within words, and sentences, not using commas and full stops properly.

(3) 76 respondents over 96 (79.16\%) agree that English sounds are difficult to pronounce. The Arabic alphabet is is not having many sounds that exist in English and because of this, many dissimilarities can be noticed easily in the way sounds are produced in Al Ula campus and other places in the kingdom. The sound ' $p$ ' "Pepsi" meaning "soft drink" pronounced as "b", becomes "bebsi" and the sound "th" as in the words "this" or "that," they tend to change it into a "z" or a "d" sound, "dakî", meaning "smart," becomes "zaki."

(4) 61 respondents over $96(63.54 \%)$ agree that there is always a fear of mistake in the mind while speaking English, specially in the class or in the groups. There is a proverb in English "Practice make a man perfect." Researcher believes that this is the only way (Mantra) to remove fear from the mind. One need to practice regularly, gradually confidence will come. Students of optional courses just think of passing the course, they somehow manage to get $60 \%$ and pass. If this attitude continues, fear will always be there.

(5) 51 respondents over $96(53.12 \%)$ disagree that learning English language is today's demand. Majority of the respondents are clear that there is no need to learn any additional foreign language, i.e.; English. They think, they don't have to go out of their city/country. They have to concentrate on their main subject and look for the career in and around their main subject, Arabic/ Islamic studies. On the other hand, respondents of Al Ula rarely come across any activity where they use English as a language. Only 16 out of $96(16.66 \%)$ are talking about learning global language.

(6) 64 respondents over $96(66.66 \%)$ agree that cultural differences affecting their learning. This is varying depending on the economic, social and cultural background of the students. Culture is intrinsic to language. Though culture has always been an element in English language learning across globe. Cultural influence of both the innate and focused cultures makes an impact on learning styles. Most of the students in Al Ula branch are from 
remote areas having limited excess of educational environment which restrict them to their native language.

(7) 47 respondents over $96(48.95 \%)$ disagree with the social networking sight like Face Book, Twitter, and Instagram helping in learning English language, where as 40 out of 96 respondents (41.66\%) agree about social networking sights which are helpful in learning English language. Those who are agrees, they feel a good start can be made in learning and improving their English language through Facebook and other social sights. Those who disagree with above points either they are not aware about it or they don't feel comfort in using language other than their mother tongue.

\section{Conclusion}

The result signifies that most of the students of compulsory English language course at Taibah University, Al Ula campus facing some socio-cultural limitations. They are not familiar about the importance of English. Their interest has not been developed by their parents, society, primary and secondary school teachers. They are very clear in their objectives to just secure $60 \%$ marks to pass English language course. While in the focus group discussion (FGD), it has been discovered that they hardly read, write, and speak a single sentence in the English language at their homes, schools and now in the university. Some of the informants even try some time to speak and read English has been discouraged. Data clearly indicates, there is a lack of motivation from learners' side, which need to be address carefully. As English is the medium of instruction in all the universities of Saudi Arabia which is not followed seriously, if only medium of instruction is going to be followed by the teachers religiously, there is a chance to motivate this category of learners to learn English language.

\section{Recommendations and Suggestions}

Language is a means of communication and there is a need to highlight significance of oral communication. Since oral communication is not the part of grade testing and evaluation, majority of the students manage to overlook this section. If the design of the course is to equip students with effective communication skills, some grades should be allocated to the production of speech in the target language. Selection and compilation of materials is very important and must be cautiously and carefully design in order to compile curriculum which is suitable for the needs and culture of students. Primary and secondary schools teaching plan should conduct a thorough analysis so that teachers and courses can match the needs, interests, and levels appropriate for the students in learning a foreign language (English). 


\section{References}

Al-Ahaydib, M. E. (1986). Teaching English as a foreign language in the intermediate and secondary schools of Saudi Arabia: diagnostic study. PhD thesis, Kansas: University of Kansas.

Al-Nasser, A. S. (2015). Problems of English Language Acquisition in Saudi Arabia: An Exploratory-cum-remedial Study. Theory and practice in language studies, (5:8) Aug 2015, 1612-1619.

Alptekin, C. (1993). Target-language culture in EFL materials. ELT Journal, 47(2), 136-143.

Al-Qadi NS. (1992). “Acquisition of English derivational morphology by Arab Speakers", Diss. University of Georgia, Athens.Asiri I (1996). University EFL teachers' written feedback on compositions and students' reactions, Essex University, UK.

Banks, J. A., Banks, \& McGee, C. A. (1989). Multicultural education. Needham heights, MA: Allyn \& Bacon.

Bartley, D. E. (1969). A pilot study and attitude factor in language dropout. California journal of Educational Research, 20, 48-55.

Elyas, T., \& Picard, M. (2010). Saudi Arabian educational history: Impacts on English language teaching. Education, business and society. Contemporary Middle Eastern Issues, $3(2), 136145$.

Khan, Intekhab.A. (2011). An analysis of learning barriers: The Saudi Arabian context. International Education Studies, 4(1), 242-247.

Lado R. (1957). Linguistics across culture. Ann Arbor, Univ. of Michigan press, p. 5.

Leng, H. (1997). New bottles, old wine: Communicative language teaching in China. English Teaching Forum, 35(4), 38-40.

Rabab'ah, G. (2003). Communication problems facing Arab learners of English. Journal of Language and Learning (pp. 180-197) Vol 3 No 1 ISSN 1740-4983.

Rabab'ah, G. (2005). Communication problems facing Arab learners of English. Grazer LinguistischeStudien, 63(Spring), 63-75.

Rahman, M. M. (2013). Teaching English in Saudi Arabia: Prospects and Challenges. Academic Research International, Vol.4, No.1. January 2013, 112-118.

Soliman, Tariq. (2014). Learning English in Saudi Arabia: a socio- cultural perspective. International Journal of English Language and Linguistics Research, Vol. 2, No. 3, pp. 56-78, December 2014.

Tylor, E. B. (1974). Primitive culture: researches into the development of mythology, philosophy, religion, art, and custom. New York: Gordon Press. First published in 1871.

Wahba, E. (1998). Teaching pronunciation-Why? Language Teaching Forum. Vol. 36, No. 3: 
32.

Wei, Y. (2005). Integrating Chinese culture with TEFL in Chinese classroom. Sino-US English Teaching, 2(7), 55-58.

Weiqiao Fan. (2009). Are achievement motivation and thinking styles related? A visit among Chinese university students.Learning and individual differences, Vol. 19, issue 2, June 2009, 299-303.

West, Richard L. Turner Lynn H. (2010). Introducing communication theory: analysis and application. Boston: McGraw-Hill.

\section{Copyright Disclaimer}

Copyright for this article is retained by the author(s), with first publication rights granted to the journal.

This is an open-access article distributed under the terms and conditions of the Creative Commons Attribution license (http://creativecommons.org/licenses/by/3.0/). 